\title{
Perbandingan Kualitas Layanan Dua Aplikasi Transportasi Online Menggunakan Metode Servqual
}

\author{
Fransiska Prihatini Sihotang ${ }^{1}$, Desi Pibriana*2, ${ }^{* 2}$ ardiani $^{3}$ \\ 1,2,3Program Studi Sistem Informasi, STMIK Global Informatika MDP \\ e-mail: ${ }^{1}$ fransiskaps@mdp.ac.id,*2desi.pibriana@mdp.ac.id, ${ }^{3}$ mardiani@mdp.ac.id
}

\begin{abstract}
Abstrak
Internet sudah menjadi hal yang sangat dibutuhkan oleh sebagian besar masyarakat di Indonesia. Penggunaan internet saat ini bukan hanya sekedar untuk membantu pekerjaan, tetapi bahkan menjadi gaya hidup seperti mengakses berita, menggunakan media sosial, belanja online, bahkan untuk menggunakan layanan transportasi online. Saat ini sudah sangat banyak perusahaan yang menyediakan jasa layanan berbasis aplikasi online yang menyebabkan persaingan antar perusahaan. Untuk menjaga kesetiaan pelanggan, perusahaan harus dapat memastikan bahwa layanan aplikasi yang diberikan lebih tinggi atau setidaknya sama dengan persepsi pelanggan. Penelitian ini membahas tentang pengukuran kualitas layanan aplikasi transportasi online di Indonesia. Penelitan ini bertujuan untuk mengetahui apakah kualitas layanan aplikasi yang diberikan oleh PT ABC dan XYZ Pte. Ltd. sudah sesuai dengan harapan pelanggan. Metode yang digunakan adalah metode analisis Servqual yang memiliki lima dimensi pengukuran yaitu tangible, reliability, responsiveness, assurance, dan emphaty. Pengumpulan data dilakukan melalui kuesioner yang diisi oleh pengguna layanan kedua aplikasi transportasi online.Hasil dari penelitian ini diketahui bahwa aplikasi yang dimiliki oleh PT ABC dan XYZ Pte. Ltd. belum memberikan kualitas layanan yang sesuai dengan harapan pelanggan karena semua dimensi pengukuran menunjukkan bahwa harapan lebih tinggi dibandingkan dengan persepsi pelanggan. Dimensi assurance pada kedua aplikasi yang diteliti memiliki gap yang berada pada urutan dua teratas paling besar pada hasil analisis data yang dilakukan. Hal ini mengindikasikan bahwa pelanggan mengharapkan keamanan yang tinggi dari kedua aplikasi tapi belum bisa dipenuhi oleh perusahaan penyedia aplikasi.
\end{abstract}

Kata kunci - Servqual, Transportasi, Transportasi Online, Service, Kualitas Layanan

\begin{abstract}
The internet has become something that is needed by most people in Indonesia. Nowadays, Internet was used by people not only just as a tool to help their work, but also as a lifestyle such as accessing the news, using a social media, online shopping or even online transportation. There were so many companies provide an online application-based services, which is one of many reason that causes competition between companies. To maintain customer loyalty, company have to ensure that the application services that provided were higher or at least met the customer perceptions. This study aims to determine whether the application services quality that provided by PT ABC and XYZ Pte. Ltd. is already met the customer expectations. Servqual method that consist of five dimensions of measurement such as tangible, reliability, responsiveness, assurance, and empathy was used in this study with questions tailored to electronic services. Data collection was carried out using a questionnaire. The result of this study showed that the Application of PT ABC and XYZ Pte. Ltd. Was not provided a service
\end{abstract}


quality that met the customer expectations yet. All dimensions of measurement show that customer expectations was higher than customer perceptions. The dimensions of Assurance in both researched application is the top second biggest gap on both of the data analyzed. This indicated that customers expect a better security from both applications which has not been fulfilled by the application provider company yet.

Keywords - :Servqual, Transportation, OnlineTransportation, Service, Service Quality

\section{PENDAHULUAN}

$\mathrm{T}$ eknologi informasi berkembang dengan sangat pesat hampir pada seluruh aspek kehidupan. Hal tersebut seiring dengan perkembangan internet yang memungkinkan penyebaran informasi terjadi dengan sangat cepat. Indonesia merupakan negara dengan penggunaan internet terbesar ketiga di Asia setelah China dan India [1]. Pengguna internet di Indonesia pada tahun 2018 berjumlah 171,17 juta jiwa atau meningkat sebanyak 27,91 juta jiwa dibandingkan tahun 2017 yang berjumlah 143,26 juta jiwa [2]. Dari pengguna internet di Indonesia tersebut, sebanyak 93,9\% pengguna mengakses internet menggunakan smart-phone atau HP setiap hari [2]. Data tersebut mencerminkan bahwa minat masyarakat di Indonesia untuk menggunakan internet sangat tinggi, khususnya menggunakan perangkat mobile.

Indonesia berada pada posisi keempat dari negara dengan jumlah penduduk terbanyak di dunia setelah RRC, India, dan Amerika Serikat. Jumlah penduduk yang besar dan tingginya minat masyarakat terhadap internet, menyebabkan pertumbuhan ekonomi digital yang cukup tinggi yang ditandai dengan munculnya perusahaan perintis (start-up) yang bergerak di berbagai bidang seperti transportasi online, e-commerce, financialtechnology (fin-tech), dan biro perjalanan wisata/ agen travel [3]. Hingga saat ini, dua start-up transportasi online yang paling banyak digunakan di Indonesia adalah PT ABC dan XYZ Pte. Ltd. [4].

Pelanggan pada dasarnya akan melakukan penilaian dalam setiap transaksi yang dilakukannya, baik itu transaksi konvensional maupun transaksi digital. Semakin baik layanan yang diberikan oleh penyedia jasa, maka semakin besar kemungkinan pelanggan untuk kembali menggunakan layanan tersebut. Anderson dan Zeithaml (1984) serta Philips, Chang, dan Buzzel (1983), mengatakan bahwa keputusan pembelian pelanggan dipengaruhi oleh kualitas yang dianggap sebagai faktor keputusan pembelian yang paling penting [5]. Kepuasan pelanggan berkaitan dengan perbandingan antara persepsi pelanggan terkait layanan yang diterima dengan harapan pelanggan terhadap layanan yang diinginkannya. Kualitas layanan terbaik akan didapatkan ketika harapan pelanggan terlampaui, sementara di sisi lain kualitas layanan dianggap tidak dapat diterima ketika harapan tidak dipenuhi, serta kualitas layanan dianggap memuaskan ketika persepsi pelanggan sesuai dengan harapan [6]. Perbedaan antara harapan pelanggan dan layanan yang diberikan oleh perusahaan menimbulkan gap yang jika tidak disiasati dengan bijaksana dapat merugikan perusahaan. Namun, sebenarnya gap tersebut dapat ditransformasikan menjadi strategi dan tindakan yang efektif untuk mencapai keunggulan kompetitif [7].

E-service dapat didefinisikan sebagai layanan pelanggan yang interaktif, berfokus pada konten berbasis internet, berorientasi pada pelanggan, dan terintegrasi dengan pendukung, teknologi, serta sistem yang ditawarkan oleh penyedia layanan untuk memperkuat hubungan antara pelanggan dengan penyedia layanan [8]. Sedangkan yang dimaksud dengan pelanggan adalah pihak yang membeli dan mengkonsumsi jasa, sehingga pelangganlah yang akan menilai kualitas jasa sebuah perusahaan. Demikian pula dengan pelanggan yang menggunakan aplikasi mobile, mereka akan menilai kualitas jasa dari layanan mobile (e-service) yang digunakannya 
[9].Salah satu metode yang dapat digunakan untuk mengukur kualitas layanan adalah metode servqual. Metode servqual menggunakan lima dimensi pengukuran untuk mengukur tingkat persepsi pelanggan terhadap kualitas layanan dan pengaruhnya terdadap kepuasan pelanggan. Lima dimensi tersebut adalah Tangibles, Reliability, Responsiveness, Assurance, dan Empathy [6].

Penelitian untuk mengukur kepuasan pelanggan sudah cukup sering dilakukan sebelumnya. Analisis tingkat kualitas layanan website perguruan tinggi menggunakan dimensi pengukuran metode servqual yang telah dimodifikasi yaitu Usability, InformationQuality, ServiceReliability, Assurance, serta Empathy menunjukkan bahwa layanan website yang tersedia pada perguruan tinggi tersebut memiliki kekurangan yang ditunjukkan dari lebih tingginya harapan daripada persepsi pengguna terhadap layanan website [10].

Penelitian lainnya yaitu merancang model pengukuran kualitas layanan elektronik dengan megadopsi model Kano yang dapat digunakan oleh penyedia layanan elektronik untuk mengukur kualitas layanan serta dapat menjadi dasar untuk mengembangkan layanan elektronik yang lebih baik. Dalam penelitian ini, digunakan 5 dimensi kualitas layanan elektronik yaitu reliability, security\&trust, websitequality, informationquality, serta interactionquality yang menunjukkan bahwa pengguna layanan elektronik di Indonesia mengharapkan faktor reliability, security\&privacy, keakuratan informasi, dan responsiveness dapat dipenuhi oleh penyedia layanan elektronik. Faktor-faktor ini mengindikasikan dampak yang signifikan terhadap ketidakpuasan pengguna berdasarkan perhitungan statistik yang dilakukan dalam penelitian [8].

Kualitas layanan websitee-commerce dapat diukur dari Tangibles, Reliability, Assurance, Responsiveness, serta Empathy. Tangibles merujuk pada tampilan fisik, struktur, layout, tema, dan lainnya dari website e-commerce yang merujuk pada struktur website. Reliability menggambarkan "kecukupan website", yaitu website e-commerce dituntut untuk menyediakan informasi yang relevan dan dibutuhkan oleh pelanggan ketika mengakses website. Assurance dapat disebut sebagai "keamanan website" yang merujuk pada penyedia layanan terpercaya termasuk juga memiliki website yang bereputasi baik, metode pembayaran yang andal, dll. Responsiveness merujuk pada respon yang cepat dan relevan terhadap permintaan khusus dari pelanggan yang sering dikenal dengan "tanggapan website". Dan Empathy yakni mengetahui pelanggan internal secara individual, mengerti kebutuhan dan kekhawatiran pelanggan seperti menyediakan rekomendasi yang sesuai dengan kebutuhan pelanggan yang sering disebut sebagai "kustomisasiwebsite" di dunia website [11].

Penelitian tentang pengaruh e-servicequality terhadap e-satisfaction serta e-loyalty pelanggan Go-jek menunjukkan bahwa kualitas layanan penting untuk diperhatikan karena dianggap sebagai suatu strategi yang penting untuk berhasil di lingkungan yang kompetitif saat ini. Fenomena kualitas layanan bertujuan untuk memperbaiki pemenuhan kepercayaan konsumen terhadap pelayanan yang diterima, yang dalam hal ini di antaranya terpenuhinya harapan, keinginan, serta kebutuhan konsumen. Adapun harapan konsumen yakni cepat mendapatkan pelayanan, keinginan konsumen yakni mendapatkan pelayanan yang sesuai dengan jangkauan pembiayaan yang dikenakan, serta kebutuhan konsumen yakni terpenuhinya layanan yang berkualitas sehingga dapat tercipta dampak positif yaitu loyalitas pelanggan secara berkesinambungan [12]. Sedangkan jika dilihat berdasarkan hasil perbandingan nilai user experience, diketahui bahwa rata-rata nilai mobileapps Gojek lebih tinggi dibandingkan nilai rata-rata pada Grab. Ltd. Hal ini dimungkinkan oleh kemunculan Gojek yang lebih dulu sehingga memungkinkan Gojek dapat lebih memahami keinginan penggunanya [13].

Banyaknya pelanggan yang menggunakan aplikasi yang disediakan oleh PT ABC dan XYZ Pte. Ltd., mengindikasikan bahwa kedua aplikasi tersebut memberikan layanan yang tinggi bagi pelanggan. Penelitian ini dilakukan untuk membuktikan hal tersebut, yaitu untuk mengetahui apakah kedua aplikasi tersebut benar-benar telah memberikan kualitas layanan yang sesuai 
dengan harapan pelanggan. Tujuan lainnya yaitu untuk membandingkan kedua aplikasi agar diketahui aplikasi mana yang lebih baik dalam hal penyediaan layanan, yaitu yang paling mendekati harapan pelanggan.

\section{METODE PENELITIAN}

Penelitian ini membandingkan kualitas layanan aplikasi transportasi online milik PT ABC dengan kualitas layanan aplikasi transportasi online XYZ Pte. Ltd. Masing-masing aplikasi diukur menggunakan lima dimensi pengukuran yang terdapat pada metode servqual. Lima dimensi pengukuran tersebut dituangkan dalam bentuk pertanyaan kuesioner yang dimodifikasi agar sesuai dengan aspek-aspek layanan aplikasi mobile. Kerangka kerja yang akan digunakan pada penelitian ini dapat dilihat pada Gambar 1.

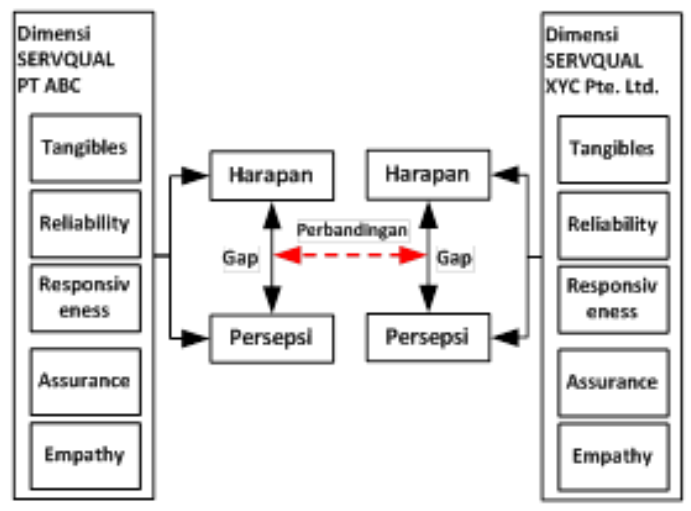

Gambar 1. Kerangka Kerja Penelitian

Gambar 1 memperlihatkan bahwa harapan pelanggan terhadap aplikasi PT ABC dibandingkan dengan persepsi pelanggan terhadap aplikasi PT ABC, begitu pula harapan pelanggan terhadap aplikasi XYZ Pte. Ltd dibandingkan dengan persepsi pelanggan terhadap aplikasi XYZ Pte. Ltd. Langkah selanjutnya adalah membandingkan hasil perbandingan yang telah didapatkan. Untuk mengetahui harapan dan persepsi pelanggan terhadap kedua aplikasi, digunakan metode pengumpulan data menggunakan kuesioner.

Metode servqual membandingkan antara sudut pandang pelanggan dengan sudut pandang penyedia layanan (provider), sehingga ditemukan gap atau ketimpangan yang seharusnya diselesaikan oleh provider agar dapat meningkatkan kepuasan pelanggan, seperti yang ditampilkan pada Gambar 2. 


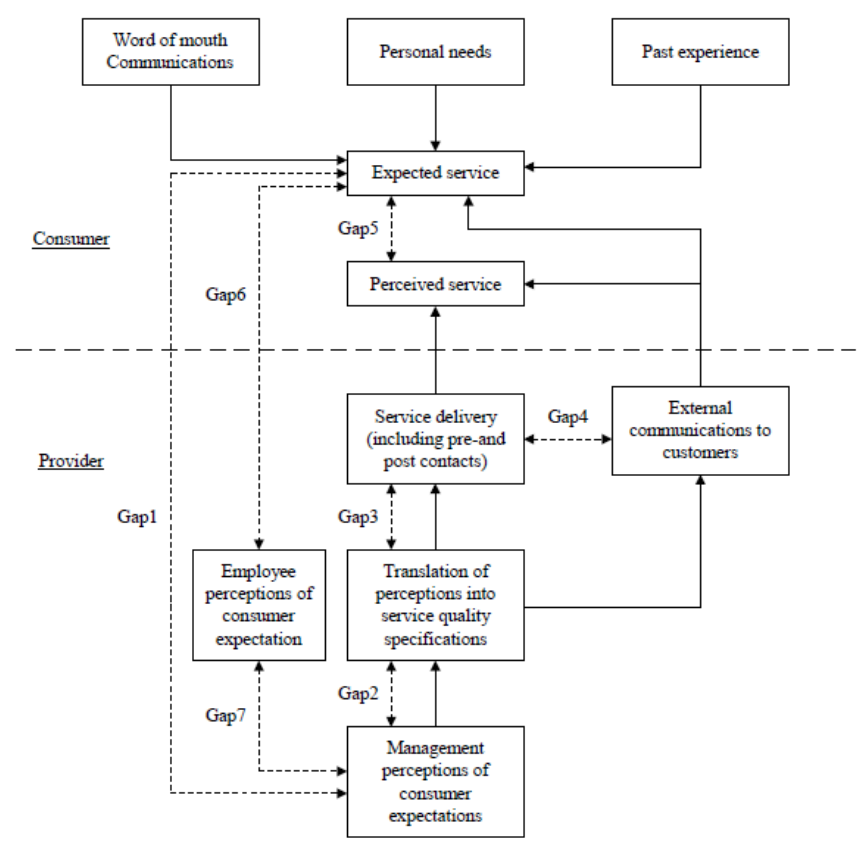

Gambar 2. Servqual Gap Model [6], [14]

Berdasarkan Gambar 2 dapat dilihat ada beberapa gap yang bisa terjadi antara pelanggan dan penyedia layanan. Gap 1 merupakan ketimpangan yang terjadi antara ekspektasi pelanggan dengan persepsi manajemen terhadap layanan yang disediakan. Ketimpangan tersebut dapat disebabkan oleh kurangnya orientasi riset pemasaran, komunikasi ke manajemen puncak yang kurang memadai, serta terlalu banyak lapisan manajemen yang terlalu banyak [14].

Adapun Gap 2 merupakan ketimpangan yang terjadi antara persepsi manajemen atas harapan pelanggan dengan terjemahan persepsi tersebut ke dalam spesifikasi layanan yang diberikan oleh provider. Hal tersebut dapat disebabkan oleh komitmen pada kualitas layanan, standarisasi tugas yang tidak memadai, serta tidak adanya penetapan tujuan [14].

Gap 3 merupakan ketimpangan yang terjadi antara terjemahan persepsi ke dalam spesifikasi kualitas layanan dengan penyampaian layanan yang dilakukan oleh provider sebagai akibat dari ambiguitas dan konflik peran, kinerja karyawan maupun teknologi yang buruk, sistem pengawasan yang tidak tepat, serta kurang terkontrolnya kerja tim. Sementara Gap 4 merupakan ketimpangan yang terjadi antara penyampaian layanan yang diberikan dengan komunikasi eksternal kepada pelanggan sebagai akibat dari komunikasi horizonal dalam internal provider yang kurang memadai serta adanya kecenderungan untuk terlalu mengumbar janji [14].

Gap 5 merupakan ketimpangan atau ketidaksesuaian antara harapan pelanggan dengan persepsi pelanggan terhadap layanan yang diberikan oleh provider sebagai akibat dari pengaruh yang diberikan dari sisi pelanggan dan kekurangan pada bagian dari penyedia layanan. Dalam hal ini, harapan pelanggan dipengaruhi oleh sejauh mana kebutuhan pribadi, rekomendasi dari mulut ke mulut, dan pengalaman pelanggan pada masa lalu dalam menggunakan layanan [14].

Gap 6 merupakan ketimpangan yang terjadi antara harapan pelanggan dengan persepsi karyawan tentang harapan pelanggan. Hal tersebut merupakan akibat dari perbedaan dalam memahami harapan pelanggan oleh pihak penyedia layanan di garis terdepan (yang berhubungan langsung dengan pelanggan). Sedangkan gap 7 merupakan ketimpangan yang terjadi antara persepsi karyawan dengan persepsi manajemen sebagai akibat dari perbedaan dalam memahami harapan pelanggan antara manajer dan penyedia layanan [14].

Penelitian ini berfokus pada gap 5, yaitu untuk mengukur ketimpangan antara harapan 
pelanggan terhadap layanan yang diberikan (perceivedservice) dengan persepsi pelanggan terhadap layanan yang diberikan (expectedservice). Terdapat tiga penilaian kualitas layanan berdasarkan perspektif pelanggan yaitu jika Perceived Service sama dengan Expected Service, maka kualitas layanan positif, jika PerceivedService lebih besar dari Expected Service, maka kualitas layanan ideal, dan jika Perceived Service kurang dari Expected Service, maka kualitas layanan negatif) [15].

Populasi dalam penelitian ini adalah pelanggan aplikasi PT ABC dan aplikasi XYZ Pte. Ltd. di Indonesia. Sampel yang digunakan sebanyak 203 untuk aplikasi PT ABC dan sebanyak 125 untuk aplikasi XYZ Ptd. Ltd. Kuesioner dalam penelitian ini terdiri dari 44 pertanyaan yang terdiri dari 22 pertanyaan untuk mengukur tingkat harapan pelanggan dan 22 pertanyaan untuk mengukur tingkat persepsi pelanggan. Pertanyaan kuesioner yang digunakan disusun berdasarkan lima dimensi pengukuran pada metode servqual dapat dilihat pada Tabel 1.

Tabel 1. Dimensi Servqual dan Indikator Pertanyaan

\begin{tabular}{|c|c|c|}
\hline Dimensi & Indikator & Kode \\
\hline \multirow[t]{6}{*}{ Tangible } & Tampilanmenarik & Tan 1 \\
\hline & Tampilantidakmembingungkan & Tan2 \\
\hline & Kejelasan menu atau link sertapenempatannya yang proporsional & $\operatorname{Tan} 3$ \\
\hline & Tata bahasa yang sopan, baik dan benar, sertamudahdimengerti & $\operatorname{Tan} 4$ \\
\hline & Navigasitidakmembingungkan & Tan5 \\
\hline & Kesempurnaantampilan di bebagaiperangkat mobile & Tan6 \\
\hline \multirow[t]{8}{*}{ Reliability } & Kontenaplikasiterkaittransportasi online & Rel1 \\
\hline & Fasilitaspencarianberfungsidenganbaik & Rel2 \\
\hline & Informasibermanfaat, lengkap, dan jelas & Rel3 \\
\hline & Informasiselalu update & Rel4 \\
\hline & Informasiakurat & Rel5 \\
\hline & Kesesuaianpemotongansaldodenganperkiraanbiayasaatmelakukanpemesanan & Rel6 \\
\hline & Kesesuaian menu denganlayanan yang diberikansertadapatdiakses & Rel7 \\
\hline & Kecepatanaktifaplikasisetelahperbaikan & Rel8 \\
\hline \multirow[t]{3}{*}{ Responsiveness } & Formulir pada aplikasiberfungsidenganbaik & Res 1 \\
\hline & Aplikasimemberikanpemberitahuanketikaterdapatinformasibaru & Res2 \\
\hline & Respon/ jawaban yang cepatsertadapatdihubunginya e-mail kontakinformasi yang ada & Res3 \\
\hline \multirow[t]{3}{*}{ Empathy } & Kenyamanandalammenggunakanaplikasi & Em1 \\
\hline & $\begin{array}{c}\text { Kemampuanaplikasidalammemberikan saran kepadapelanggandalampencarianlayanan yang } \\
\text { dibutuhkan }\end{array}$ & Em2 \\
\hline & Kemampuanaplikasidalammengertikebutuhanpelanggan & Em3 \\
\hline \multirow[t]{2}{*}{ Assurance } & Keamananaplikasiterjamin & As1 \\
\hline & Reputasiperusahaanpenyediaaplikasi & As2 \\
\hline
\end{tabular}

Kuesioner yang dibuat berdasarkan lima dimensi pengukuran servqual menggunakan lima poin skala likertyang dapat dilihat pada Tabel 2.

Tabel 2. Skala Likert yang Digunakan

\begin{tabular}{|c|c|}
\hline Harapan & Persepsi \\
\hline 1 = Tidak Penting (TP) & $1=$ Sangat Buruk (SB) \\
\hline 2 = Kurang Penting (KP) & $2=$ Buruk (B) \\
\hline 3 = Netral (N) & $3=$ Netral (N) \\
\hline 4 = Penting (P) & $4=$ Baik (B) \\
\hline 5 = Sangat Penting (SP) & 5= Sangat Baik (SB) \\
\hline
\end{tabular}

Sesuai dengan tujuan penelitian yaitu mengetahui gap antara harapan pelanggan terhadap layanan yang diberikan (perceivedservice) dengan persepsi pelanggan terhadap layanan yang diberikan (expectedservice), maka kuesioner penelitian pun dibagi menjadi dua kelompok pertanyaan yaitu kelompok harapan dan kelompok persepsi dengan indikator pertanyaan yang sama persis. 
Pada kelompok harapan pelanggan terhadap layanan yang diberikan, responden dapat memilih nilai antara 1 sampai 5 yang mewakili nilai tidak penting, kurang penting, netral, penting, dan sangat penting. Jika responden memilih nilai 1, maka responden merasa bahwa hal yang diajukan pada butir pertanyaan terkait bersifat tidak penting, atau bukan menjadi hal yang diharapkan pelanggan terhadap kualitas layanan yang diberikan. Sedangkan jika responden memilih nilai 5, maka responden merasa bahwa hal yang diajukan pada butir pertanyaan terkait bersifat sangat penting dan menjadi hal yang sangat diharapkan pelanggan terhadap kualitas layanan yang diberikan.

Sedangkan pada kelompok persepsi harapan pelanggan terhadap layanan yang diberikan, responden juga dapat memilih nilai antara 1 sampai 5 yang mewakili nilai sangat buruk, buruk, netral, baik, dan sangat baik. Jika responden memilih nilai 1, maka responden menilai bahwa hal yang diajukan pada butir pertanyaan terkait bernilai sangat buruk. Dengan kata lain, untuk butir pertanyaan terkait, penyedia layanan memberikan kualitas layanan yang buruk dan sangat tidak sesuai dengan harapan pelanggan. Sedangkan jika responden memilih nilai 5 , maka responden menilai bahwa hal yang diajukan pada butir pertanyaan terkait bernilai sangat baik atau penyedia layanan telah memberikan kualitas layanan yang sudah sangat sesuai dengan yang diharapkan pelanggan.

\section{HASIL DAN PEMBAHASAN}

\subsection{Responden Penelitian}

Responden pada penelitian ini dibagi menjadi 2 kelompok, yaitu responden pengguna layanan yang disediakan oleh PT ABC dan responden pengguna layanan yang disediakan oleh XYZ Pte. Ltd. Kuesioner disebarkan dengan memanfaatkan formulir elektronik dan ketika kuesioner yang telah diisi dikembalikan oleh para responden, ternyata terdapat perbedaan jumlah responden dari kedua aplikasi, yaitu 203 responden merupakan pengguna aplikasi layanan PT ABC dan 125 responden merupakan pengguna aplikasi layanan XYZ Pte. Ltd.

Adapun responden pengguna layanan yang disediakan oleh PT ABC berjumlah 203 orang yang terdiri dari 88 orang perempuan dan 115 orang laki-laki, atau $43 \%$ berbanding $57 \%$ seperti yang terlihat pada Gambar 3.

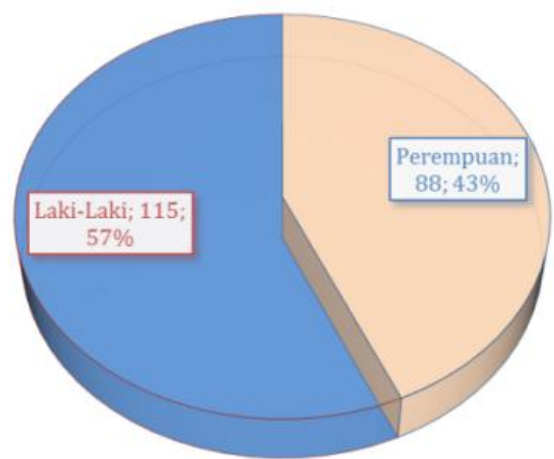

Gambar 3. Sebaran Responden PT ABC Berdasarkan Jenis Kelamin

Responden pengguna layanan PT ABC tersebar di 13 provinsi di Indonesia. Namun, didominasi oleh responden yang berasal dari provinsi Sumatera Selatan seperti yang terlihat pada Tabel 3. 
Tabel 3. Sebaran Responden PT ABC Berdasarkan Provinsi

\begin{tabular}{|c|c|}
\hline Provinsi Domisili & Jumlah Responden \\
\hline Banten & 4 \\
\hline Jakarta & 9 \\
\hline Jambi & 4 \\
\hline Jawa Barat & 7 \\
\hline Jawa Tengah & 4 \\
\hline Jawa Timur & 3 \\
\hline Kalimantan Selatan & 1 \\
\hline Kepulauan Bangka Belitung & 5 \\
\hline Kepulauan Riau & 1 \\
\hline Riau & 1 \\
\hline Sulawesi Selatan & 1 \\
\hline Sumatera Selatan & 160 \\
\hline Yogyakarta & 3 \\
\hline
\end{tabular}

Sebaran jumlah responden yang menggunakan layanan dari PT ABC dalam penelitian ini didominasi oleh pelajar/ mahasiswa, pegawai swasta, dan guru atau dosen sesuai dengan yang tercantum pada Gambar 4.

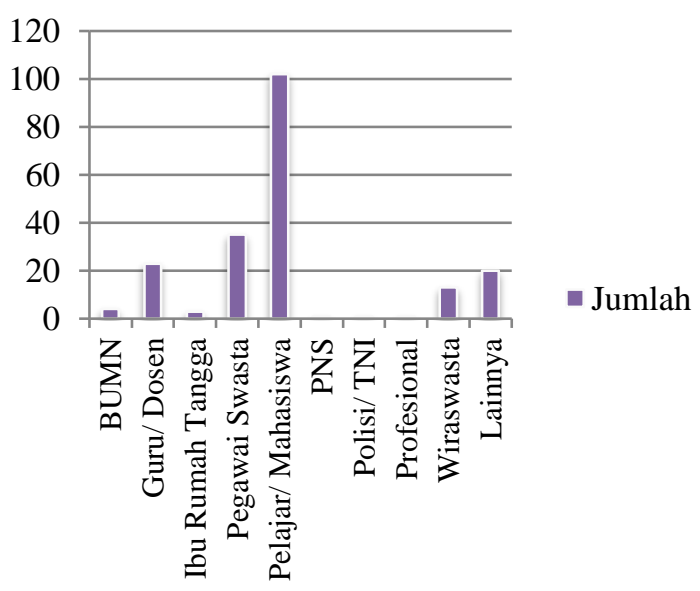

Gambar 4. Sebaran Responden PT ABC Berdasarkan Pekerjaan

Sedangkan jika dilihat dari rentang usia, responden yang menggunakan layanan PT ABC didominasi oleh kelompok usia produktif yakni antara 17 hingga 34 tahun, seperti yang terlihat pada Gambar 5.

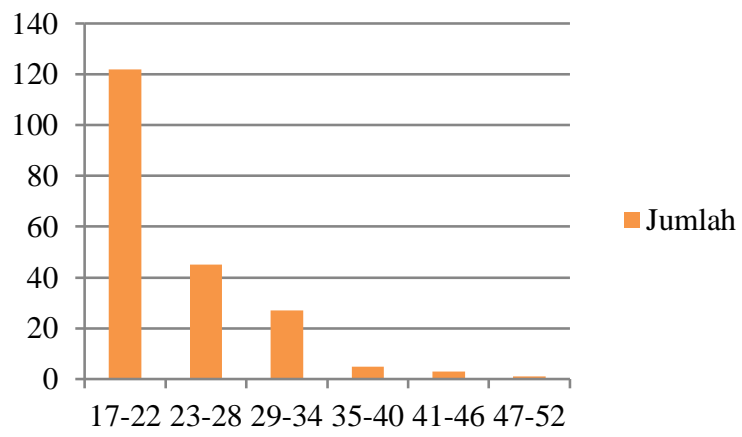

Gambar 5. Sebaran Data Responden PT ABC Berdasarkan Usia

Sementara total responden yang menggunakan layanan XYZ Pte. Ltd. yang pendapatnya berhasil dihimpun melalui kuesioner penelitian ini berjumlah 125 orang yang 
terdiri dari 66 orang perempuan dan 59 orang laki-laki, atau $53 \%$ berbanding $47 \%$ sesuai dengan yang tertera pada Gambar 6.

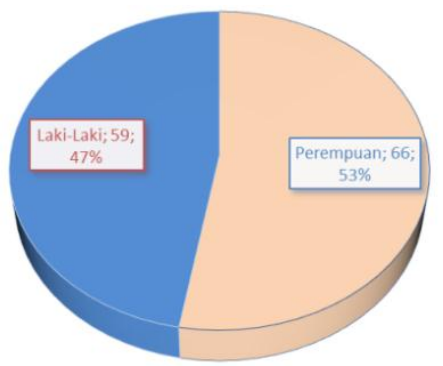

Gambar 6. Sebaran Responden XYZ Pte. Ltd. Berdasarkan Jenis Kelamin

Responden XYZ Pte. Ltd. berasal dari 11 provinsi yang ada di Indonesia. Responden terbanyak juga berasal dari provinsi Sumatera Selatan seperti yang terlihat pada Tabel 4. Sama halnya dengan PT ABC, responden XYZ Pte. Ltd. juga didominasi kalangan pelajar/ mahasiswa, pegawai swasta, dan guru atau dosen seperti yang terlhat pada Gambar 7. Sedangkan jika dilihat dari rentang usia, responden berasal dari kalangan usia 17 hingga 34 tahun sebagaimana yang terlihat pada Gambar 8.

Tabel 4.Sebaran Responden XYZ Pte. Ltd. Berdasarkan Provinsi

\begin{tabular}{|c|c|}
\hline Provinsi Domisili & Jumlah Responden \\
\hline Banten & 3 \\
\hline Jakarta & 10 \\
\hline Jambi & 2 \\
\hline Jawa Barat & 6 \\
\hline Jawa Tengah & 3 \\
\hline Jawa Timur & 1 \\
\hline Kalimantan Selatan & 1 \\
\hline Kepulauan Bangka Belitung & 6 \\
\hline Kepulauan Riau & 1 \\
\hline Sumatera Selatan & 91 \\
\hline Yogyakarta & 1 \\
\hline
\end{tabular}

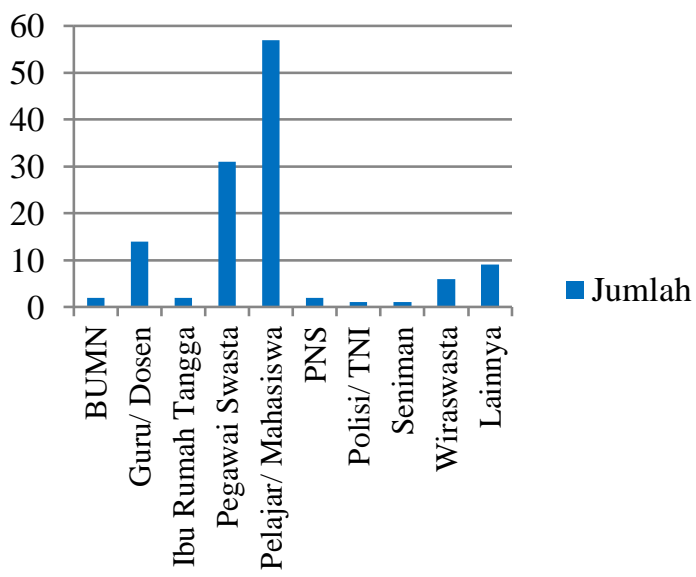

Gambar 7. Sebaran Responden XYZ Pte. Ltd. Berdasarkan Pekerjaan 


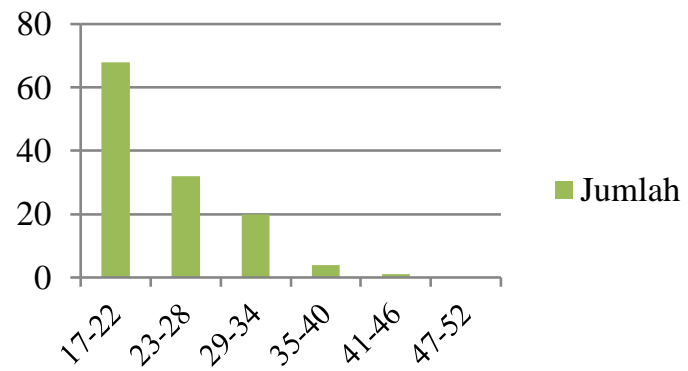

Gambar 8. Sebaran Responden XYZ Pte. Ltd. Berdasarkan Usia

Dari kedua data demografi responden yang telah diuraikan, terlihat bahwa penyebarannya memang tidak merata, khususnya sebaran data berdasarkan provinsi domisili yang sangat dominan berasal dari Sumatera Selatan. Tetapi mengingat topik penelitian yang membahas kualitas layanan yang disediakan oleh PT ABC dan XYZ Pte. Ltd., dirasa hal ini tidak berpengaruh terhadap lokasi domisili responden. Berdasarkan pekerjaan dan usianya, responden kedua perusahaan ini didominasi oleh pelajar/ mahasiswa, pegawai swasta, serta guru atau dosen yang berada pada rentang usia muda produktif yaitu antara 17 - 34 tahun yang memang banyak menggunakan layanan transportasi online untuk memenuhi kebutuhan keseharian maupun gaya hidupnya.

\subsection{Uji Validitas dan Reabilitas}

Sebelum dilakukan pengolahan data, terlebih dahulu dilakukan pengujian terhadap instrumen penelitian untuk memastikan bahwa instrumen penelitian yang digunakan bernilai valid dan reliabel. Dalam penelitian ini terdapat dua aplikasi layanan transportasi yang akan dibandingkan, masing-masing menggunakan pertanyaan kuesioner yang sama tetapi dengan jumlah responden yang berbeda, sehingga uji validitas dan uji reliabilitas dilakukan terhadap keduanya secara terpisah. Untuk menghitung nilai validitas dari instrumen yang digunakan, maka perlu dilakukan perbandingan antara nilai corrected item total correlationpada setiap indikator atau pertanyaan dengan nilai $r$ tabel. Jika correlated item total correlation ( $r$ hitung) bernilai positif dan lebih besar dari nilai $r$ tabel, maka indikator atau pertanyaan/ pernyataan pada variabel dapat dinyatakan valid [16]. Ringkasan hasil uji validitas terhadap instrumen penelitian dapat dilihat pada Tabel 5.

Tabel 5. Ringkasan Hasil Uji Validitas Instrumen Penelitian

\begin{tabular}{|c|c|c|c|c|}
\hline \multirow[b]{2}{*}{ No } & \multirow[b]{2}{*}{ Perusahaan } & \multicolumn{3}{|c|}{ Uji Validitas (Sig. 5\%) } \\
\hline & & $\begin{array}{c}r \\
\text { tabel }\end{array}$ & $\begin{array}{c}\mathbf{r} \\
\text { Hitung }\end{array}$ & Ket \\
\hline 1. & $\begin{array}{c}\text { PT. ABC (203 Sampel) } \\
->\mathrm{df}=201\end{array}$ & 0,13 & $\begin{array}{c}0,632- \\
0,873\end{array}$ & $\begin{array}{c}\text { Vali } \\
\mathrm{d}\end{array}$ \\
\hline 2. & $\begin{array}{l}\text { XYZ Pte. Ltd (125 } \\
\text { Sampel) }->\text { df }=123\end{array}$ & 0,17 & $\begin{array}{c}0,571- \\
0,887\end{array}$ & $\begin{array}{c}\text { Vali } \\
\mathrm{d}\end{array}$ \\
\hline
\end{tabular}

Berdasarkan perhitungan yang telah dilakukan, dengan tingkat signifikansi (error) sebesar 5\%, nilai $r$ tabel PT ABC dengan sampel sebanyak $203(\mathrm{df}=201)$ adalah 0,13 dan $r$ hitunguntuk setiap butir pertanyaan memiliki nilai dengan kisaran antara 0,632 s.d. 0,873. Sedangkan untuk XYZ Pte. Ltd., dengan tingkat signifikansi sebesar 5\% dan jumlah sampel sebanyak $125(\mathrm{df}=123)$, didapatkan $r$ tabel 0,17 dan $r$ hitungsetiap butir pertanyaan memiliki nilai dengan kisaran antara 0,571 s.d. 0,887. Dengan demikian, dapat dilihat bahwa $r$ hitung $>r$ tabel sehingga tiap butir pertanyaan dinyatakan valid. 
Sedangkan untuk uji reliabilitas, digunakan nilai Cronbach'sAlpha untuk masingmasing variabel atau dimensi pengukuran. Menurut [16], jika nilai Alpha kurang dari 0,6 maka tingkat reliabilitas dari instrumen dianggap buruk, jika berkisar di 0,7 maka tingkat reliabilitas instrumen masih bisa diterima, sedangkan jika lebih dari 0,8 maka tingkat reliabilitas instrumen dianggap bagus.

Pengujian reliabilitas terhadap 44 item indikator/ instrumen penelitian dan 203 responden $\mathrm{PT} \mathrm{ABC}$, menunjukkan bahwa nilai Cronbach'sAlpha yang didapatkan untuk tiap item indikator adalah 0,985. Sedangkan hasil uji reliabilitas terhadap 44 item indikator/ instrumen penelitian dan 125 responden XYZ Pte. Ltd., menunjukkan bahwa nilai Cronbach'sAlpha yang didapatkan untuk tiap item indikator adalah 0,983. Dengan demikian dapat disimpulkan bahwa tingkat reliabilitas untuk tiap item indikator dalam penelitian ini dapat dikatakan bagus. Adapun hasil uji reliabilitas untuk kedua perusahaan yang diteliti dapat dilihat secara ringkas pada Tabel 6 .

Tabel 6. Ringkasan Hasil Uji Reliabilitas Instrumen Penelitian

\begin{tabular}{|c|c|c|c|c|}
\hline \multirow{2}{*}{ No } & \multirow{2}{*}{ Perusahaan } & \multicolumn{3}{|c|}{ Uji Reliabilitas } \\
\cline { 3 - 5 } & $\begin{array}{c}\text { Cronbach'sAlph } \\
\text { a }\end{array}$ & Hasil & Ket \\
\hline 1. & PT. ABC & $0,7-0,8$ & 0,985 & Reliabel \\
\hline 2. & XYZ Pte. Ltd & $0,7-0,8$ & 0,983 & Reliabel \\
\hline
\end{tabular}

\subsection{Analisis Gap Harapan dan Persepsi antara PT ABC dan XYZ Pte. Ltd.}

Aplikasi milik PT ABC dan XYZ Pte. Ltd. masing-masing diukur menggunakan lima dimensi pengukuran yang terdapat pada metode servqual. Harapan pelanggan terhadap aplikasi PT ABC dibandingkan dengan persepsi pelanggan terhadap aplikasi PT ABC, begitu pula harapan pelanggan terhadap aplikasi XYZ Pte. Ltd. dibandingkan dengan persepsi pelanggan terhadap aplikasi XYZ Pte. Ltd. Hasil pengolahan data dari kuesioner yang telah disebarkan dapat dilihat pada Tabel 7.

Tabel 7. Hasil Perhitungan Kuesioner

\begin{tabular}{|c|c|c|c|c|}
\hline \multirow{2}{*}{$\begin{array}{c}\text { Dimensi } \\
\text { Servqual }\end{array}$} & \multicolumn{2}{|c|}{ PT ABC } & \multicolumn{2}{c|}{ XYZ Pte. Ltd. } \\
\cline { 2 - 5 } & Harapan & Persepsi & Harapan & Persepsi \\
\hline Tangible & 4,102 & 3,846 & 4,116 & 3,768 \\
\hline Reliability & 4,088 & 3,782 & 4,052 & 3,77 \\
\hline $\begin{array}{c}\text { Responsive } \\
\text { ness }\end{array}$ & 4,03 & 3,67 & 4,07 & 3,76 \\
\hline Assurance & 4,111 & 3,773 & 4,088 & 3,736 \\
\hline Emphaty & 4,062 & 3,823 & 4,136 & 3,805 \\
\hline
\end{tabular}

Pada dimensi Tangible, rata-rata nilai harapan pelanggan untuk PT ABC yaitu 4,102, sedangkan rata-rata nilai persepsinya yaitu 3,846. Untuk XYZ Pte. Ltd., rata-rata nilai harapan pelanggan yaitu 4,116, sedangkan rata-rata nilai persepsinya yaitu 3,768. Pada dimensi Reliability, rata-rata nilai harapan pelanggan untuk PT ABC yaitu 4,088, sedangkan rata-rata nilai persepsinya yaitu 3,782. Untuk XYZ Pte. Ltd., rata-rata nilai harapan pelanggan yaitu 4,052, sedangkan rata-rata nilai persepsinya yaitu 3,77 .

Pada dimensi Responsiveness, rata-rata nilai harapan pelanggan untuk PT ABC yaitu 4,03, sedangkan rata-rata nilai persepsinya yaitu 3,67. Untuk XYZ Pte. Ltd., rata-rata nilai harapan pelanggan yaitu 4,07, sedangkan rata-rata nilai persepsinya yaitu 3,76. Pada dimensi Assurance, rata-rata nilai harapan pelanggan untuk PT ABC yaitu 4,111, sedangkan rata-rata nilai persepsinya yaitu 3,773. Untuk XYZ Pte. Ltd., rata-rata nilai harapan pelanggan yaitu 4,088, sedangkan rata-rata nilai persepsinya yaitu 3,736 . 
Sedangkan pada dimensi Emphaty, rata-rata nilai harapan pelanggan untuk PT ABC yaitu 4,062, sedangkan rata-rata nilai persepsinya yaitu 3,823. Untuk XYZ Pte. Ltd., rata-rata nilai harapan pelanggan yaitu 4,136 , sedangkan rata-rata nilai persepsinya yaitu 3,805 .

Tabel 8. Gap Harapan dan Persepsi PT ABC dan XYZ Pte. Ltd.

\begin{tabular}{|c|c|c|c|}
\hline \multicolumn{2}{|c|}{ PT ABC } & \multicolumn{2}{|c|}{ XYZ Pte. Ltd. } \\
\hline $\begin{array}{c}\text { Dimensi } \\
\text { Servqual }\end{array}$ & Gap & $\begin{array}{c}\text { Dimensi } \\
\text { Servqual }\end{array}$ & Gap \\
\hline Responsiveness & $-0,36$ & Assurance & $-0,352$ \\
\hline Assurance & $-0,338$ & Tangible & $-0,348$ \\
\hline Reliability & $-0,306$ & Emphaty & $-0,331$ \\
\hline Tangible & $-0,256$ & Responsiveness & $-0,31$ \\
\hline Emphaty & $-0,239$ & Reliability & $-0,282$ \\
\hline Rata-rata gap & $-0,2998$ & Rata-rata gap & $-0,3246$ \\
\hline
\end{tabular}

Tabel 8 memperlihatkan gap yang terjadi antara harapan dan persepsi pelanggan yang diurutkan dari gap terbesar hingga gap terkecil. Diketahui bahwa pada PT ABC terdapat gap 0,36 pada dimensi responsiveness, -0,338 pada dimensi assurance, -0,306 pada dimensi reliability, $-0,256$ pada dimensi tangible, dan $-0,239$ pada dimensi emphaty. Sedangkan pada XYZ Pte. Ltd., terdapat gap -0,352 pada dimensi assurance, -0,348 pada dimensi tangible, 0,331 pada dimensi emphaty, $-0,31$ pada dimensi responsiveness, dan $-0,282$ pada dimensi reliability.

Pada PT ABC terdapat gap paling besar pada dimensi assurance, disusul secara secara berurutan oleh dimensi responsiveness, reliability, dan tangible. Sedangkan gap paling kecil terdapat pada dimensi emphaty. Untuk XYZ Pte. Ltd, gap paling besar yaitu pada dimensi emphaty, disusul secara berurutan oleh dimensi assurance, tangible, dan responsiveness. Gap terkecil terdapat pada dimensi reliability.

Pada kedua aplikasi dapat dilihat bahwa harapan pelanggan lebih besar dibandingkan dengan persepsi pelanggan. Hal tersebut menyebabkan terjadinya gap yang mengindikasikan bahwa pelayanan yang diberikan oleh kedua aplikasi masih berada di bawah harapan pelanggan. Dengan kata lain, kedua aplikasi belum dapat memenuhi harapan pelanggan.

Walaupun masing-masing aplikasi tidak menunjukkan urutan gap yang sama persis, tapi dapat dilihat bahwa dimensi assurance pada PT ABC dan XYZ Pte. Ltd. berada pada posisi dua teratas atau memiliki gap yang cukup besar dibandingkan dengan dimensi yang lainnya. Hal tersebut mengindikasikan bahwa pengguna layanan kedua aplikasi sepakat untuk menganggap bahwa keamanan aplikasi dan reputasi penyedia layanan aplikasi sebagai hal yang penting sehingga pelanggan mengharapkan layanan yang lebih baik dari dimensi tersebut.

Namun, jika dilihat dari seluruh dimensi pengukuran, rata-rata gap yang dimiiki oleh PT ABC lebih kecil yakni hanya -0,2998 dibandingkan dengan XYZ Pte. Ltd. yang rata-rata gapnya adalah $-0,3246$, seperti yang dapat dilihat pada Tabel 8 . Hal ini mengindikasikan bahwa dari kedua aplikasi yang diteliti, aplikasi yang disediakan oleh PT ABC lebih mendekati harapan pelanggan dibandingkan dengan aplikasi yang disediakan oleh XYZ Pte. Ltd.

\subsubsection{Analisis Gap Dimensi Tangible}

Pada Gambar 9 dapat dilihat bahwa untuk dimensi tangible yang indikatornya terkait dengan tampilan aplikasi yang menarik, tidak membingungkan, kejelasan menu atau link, tata bahasa yang digunakan, navigasi, dan tampilan aplikasi jika dibuka di berbagai perangkat mobile, menunjukkan bahwa antara PT ABC dan XYZ Pte. Ltd. cukup memiliki hasil yang berbeda. Persentasenya menunjukkan $42 \%$ berbanding $58 \%$.

Hal tersebut mengindikasikan bahwa PT ABC memiliki gap yang lebih kecil antara harapan dengan persepsi dibandingkan dengan XYZ Pte. Ltd. dengan demikian dapat disimpulkan bahwa, aplikasi yang disediakan oleh PT ABC lebih memenuhi harapan pelanggan 
dari sisi tampilan fisik (dalam hal ini merupakan tampilan aplikasinya).

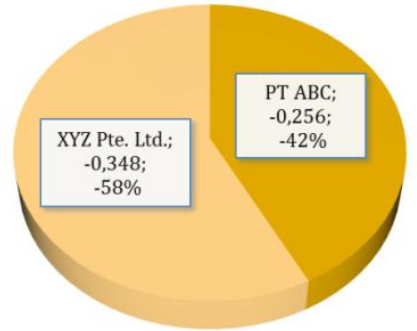

Gambar 9. Gap Harapan dan Persepsi Dimensi Tangible Antara PT ABC dan XYZ Pte. Ltd.

\subsubsection{Analisis Gap Dimensi Reliability}

Perbadingan analisis gap pada dimensi reliability pada kedua aplikasi dapat dilihat pada Gambar 10.

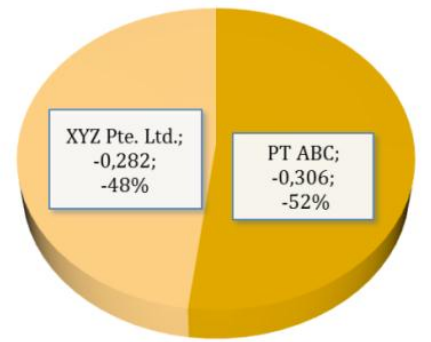

Gambar 10. Gap Harapan dan Persepsi Dimensi Reliability Antara PT ABC dan XYZ Pte. Ltd.

Untuk dimensi reliability yang indikatornya terkait dengan konten aplikasi, fasilitas pencarian, informasi yang berkualitas, kesesuaian pemotongan saldo, kesesuaian menu dengan layanan, dan kecepatan perbaikan, menunjukkan bahwa antara PT ABC dan XYZ Pte. Ltd. tidak memberikan hasil yang signifikan, yaitu $52 \%$ berbanding $48 \%$.

Namun, dalam hal ini PT ABC memiliki gap yang lebih besar dibanding dengan XYZ Pte. Ltd. yang berarti bahwa aplikasi XYZ Pte. Ltd. sedikit lebih akurat dan andal dalam memberikan pelayanan yang dijanjikan dibandingkan dengan PT ABC.

\subsubsection{Analisis Gap Dimensi Responsiveness}

Pada Gambar 11 dapat dilihat bahwa untuk dimensi responsiveness yang indikatornya terkait dengan fungsi formulir aplikasi, notifikasi, serta respon yang cepat ketika dihubungi, menunjukkan bahwa antara PT ABC dan XYZ Pte. Ltd. tidak memberikan hasil yang terlalu signifikan, yaitu 54\% berbanding 46\%. Sehingga dapat disimpulkan bahwa XYZ Pte. Ltd. sedikit lebih unggul dibandingkan dengan $\mathrm{PT}$ ABC dalam hal daya tanggap aplikasi terhadap pelanggan.

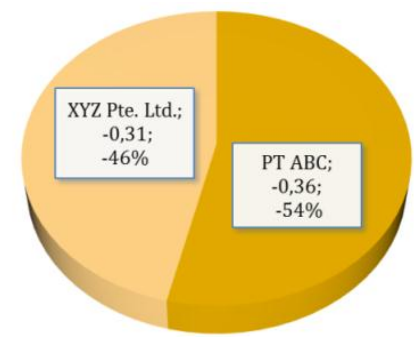

Gambar 11. Gap Harapan dan Persepsi Dimensi Responsiveness Antara PT ABC dan XYZ Pte. Ltd. 


\subsubsection{Analisis Gap Dimensi Emphaty}

Pada Gambar 12 dapat dilihat bahwa untuk dimensi emphaty yang indikatornya terkait dengan kenyamanan penggunaan aplikasi, kemampuan aplikasi dalam memberikan saran kepada pelanggan, dan mengerti kebutuhan pelanggan, antara PT ABC dan XYZ Pte. Ltd. cukup memiliki hasil yang berbeda, yaitu $42 \%$ berbanding $58 \%$.

Hal tersebut mengindikasikan bahwa PT ABC lebih peduli serta perhatian kepada pelanggan, termasuk dalam hal akses aplikasi, komunikasi, serta memahami pelanggan dibandingkan dengan XYZ Pte. Ltd.

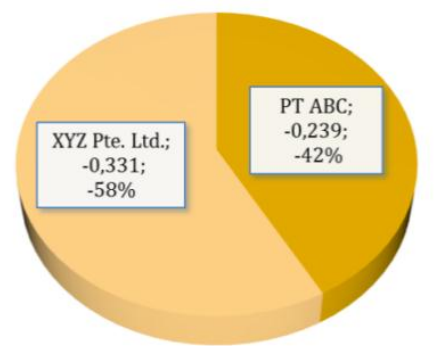

Gambar 12. Gap Harapan dan Persepsi Dimensi Emphaty Antara PT ABC dan XYZ Pte. Ltd.

\subsubsection{Analisis Gap Dimensi Assurance}

Pada Gambar 13 dapat dilihat bahwa untuk dimensi assurance yang indikatornya terkait dengan jaminan keamanan aplikasi dan reputasi perusahaan, antara PT ABC dan XYZ Pte. Ltd. memiliki hasil yang hampir sama yaitu $49 \%$ berbanding $51 \%$, atau hanya selisih sebanyak $2 \%$.

Hal tersebut mengindikasikan bahwa PT ABC hanya sedikit lebih baik dalam hal memberikan rasa percaya serta keyakinan pelanggan dibandingkan dengan XYZ Pte. Ltd.

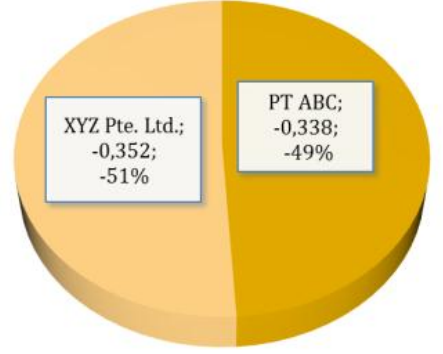

Gambar 13. Gap Harapan dan Persepsi Dimensi Assurance Antara PT ABC dan XYZ Pte. Ltd.

Berdasarkan analisis perbandingan gap yang telah dilakukan seperti yang terlihat pada Gambar 9 sampai dengan Gambar 13, diketahui bahwa PT ABC lebih baik dalam dimensi Tangible, Emphaty, dan Assurance. Sedangkan XYZ Pte. Ltd. lebih baik dalam dimensi Reliability dan Responsiveness. Kesimpulan hasil analisis perbandingan gap dapat dilihat pada Tabel 9.

Tabel 9. Kesimpulan Hasil Analisis Perbandingan Gap

\begin{tabular}{|c|c|}
\hline Dimensi & Gap yang lebih kecil/ Lebih Mendekati harapan pelanggan \\
\hline Tangible & PT ABC \\
\hline Reliability & XYZ Pte. Ltd \\
\hline Responsiveness & XYZ Pte. Ltd \\
\hline Emhaty & PT ABC \\
\hline Assurance & PT ABC \\
\hline
\end{tabular}

Untuk dimensi tangible, PT ABC lebih unggul dibandingkan dengan XYZ Pte. Ltd. 
Untuk dimensi reliability, XYZ Pte. Ltd. lebih unggul dibandingkan dengan PT ABC. Untuk dimensi responsiveness, XYZ Pte. Ltd. lebih unggul dibandingkan dengan PT ABC. Untuk dimensi emphaty, PT ABC lebih unggul dibandingkan dengan XYZ Pte. Ltd. Sedangkan untuk dimensi assurance, PT ABC lebih unggul dibandingkan dengan XYZ Pte. Ltd.

\section{KESIMPULAN DAN SARAN}

Aplikasi yang dimiliki oleh kedua perusahaan yakni PT ABC dan XYZ Pte. Ltd. belum memberikan kualitas layanan yang sesuai dengan harapan pelanggan karena dari data yang didapat, semua dimensi pengukuran menunjukkan bahwa harapan pengguna layanan lebih tinggi dibandingkan dengan persepsi pelanggan.

Dimensi assurance pada kedua aplikasi yang diteliti memiliki gap yang berada pada urutan dua teratas. Hal ini mengindikasikan bahwa pelanggan mengharapkan keamanan yang tinggi dari kedua aplikasi tetapi belum bisa dipenuhi oleh perusahaan penyedia aplikasi.

Jika dilihat dari keseluruhan dimensi pengukuran, didapatkan hasil bahwa PT ABC memiliki rata-rata gap yang lebih kecil dibandingkan dengan XYZ Pte. Ltd. Hal ini menunjukkan bahwa kualitas aplikasi yang disediakan oleh PT ABC lebih unggul dalam hal pemenuhan harapan pelanggan dibandingkan dengan aplikasi yang disediakan oleh XYZ Pte. Ltd. Dari 5 dimensi pengukuran, PT ABC lebih unggul pada 3 dimensi, yaitu pada dimensi tangible, emphaty, dan assurance. Untuk dimensi reliability dan responsiveness, XYZ Pte. Ltd. lebih memenuhi harapan pelanggan dibandingkan dengan PT ABC.

Penelitian selanjutnya dapat berfokus pada pengembangan metode analisis data dan dapat juga mengambil studi kasus pada perusahaan e-commerce selain bidang transportasi. Bagi perusahaan penyedia aplikasi, dalam hal ini yaitu PT ABC dan XYZ Pte. Ltd. dapat melakukan perbaikan terhadap tiap dimensi pengukuran servqual, agar dapat memenuhi harapan pelanggan.

\section{DAFTAR PUSTAKA}

[1] Internet World Stats Usage and Population Statistics 2018, "Asia Internet Use, Population Data and Facebook Staistick - December 2017”, [Online], Available: https://www.internetworldstats.com/stats3.htm\#asia, [Accessed: 06-Aug-2019].

[2] APJII 2018, Penetrasi \& Profil Perilaku Pengguna Internet Indonesia.

[3] M. Idris, "Indonesia Makin Melek Ekonomi Digital, Ini Datanya," Detik Finance, 12Oct-2018.

[4] Kata Data 2018, “Go-Jek, Aplikasi Transportasi Online Paling Banyak Digunakan”.

[5] U. Essays 2017, "Definition of Service Quality," UK Essays, [Online], Available: https://www.ukessays.com/essays/marketing/definition-of-service-quality-marketingessay.php?vref=1, [Accessed: 12-Oct-2018].

[6] A. Parasuraman, V. A. Zeithaml, and L. L. Berry 2009, “A Conceptual Model of Service Quality and Its Implications for Future Research," Vol. 49, No. 4, pp. 41-50.

[7] M. H. Siddiqui and T. G. Sharma 2010, "Measuring The Customer Perceived Service 
Quality for Life Insurance Services: an Empirical Investigation,” Int. Bus. Res., Vol. 3, No. 3, p. 171.

[8] D. Lestarini 2017, "Designing Kano-Based E-Service Quality Model to Improve User Satisfaction,", No. November, pp. 147-152.

[9] Y. S. Widiaputri, Suharyon, and A. S. Bafadhal 2018, "Pengaruh E-Service Quality Terhadap Perceveid Value dan E- Customer Satisfaction (Survei pada Pelanggan GoRide yang Menggunakan Mobile Application Go-Jek di Kota Malang )," Vol. 61, No. 1, pp. $1-10$.

[10] D. P. Kesuma 2014, "Analisis Pengukuran Kualitas Layanan Web Perguruan Tinggi XYZ Menggunakan Servqual,” in Seminar Nasional Informatika, pp. 178-183.

[11] U. Essays 2017, "Website Attributes On Customer Satisfaction In E-Commerce," Uk Essays, [Online], Available: https://www.ukessays.com/essays/ecommerce/websiteattributes-customer-satisfaction-4091.php?vref=1. [Accessed: 12-Oct-2018].

[12] Melinda 2017, "Pengaruh E-Serice Quality Terhadap E-Loyality Pelanggan Go-Jek Melalui E-Satisfaction Pada Kategori Go-Ride," Agora, Vol. 5, No. 1.

[13] A. Chan, M. Maharani, and P. W. Tresna 2017, "Perbandingan Pengalaman Pengguna pada Aplikasi Mobile Go-Jek dan Grab (Studi pada Konsumen Pt Go-Jek dan Pt Grab Indonesia di Dki Jakarta)," AdBispreneur, Vol. 2, No. 2.

[14] A. Shahin 2006, "Servqual and Model of Service Quality Gaps: A Framework for Determining and Prioritizing Critical Factors in Delivering Quality Services,"

[15] F. L. Budiono 2013, "Persepsi dan Harapan Pengguna Terhadap Kualitas Layanan Data pada Smartphone di Jakarta User Perception and Expectation," Bul. Pos dan Telekomun., vol. 11, no. 2, pp. 93-108.

[16] I. Ghozali 2007, Analisis Multivariate Dengan Program SPSS, 5th ed. Semarang: Universitas Diponegoro, 